\title{
Sebastião Rodrigues Soromenho: um piloto português nos navios da rota de Manila ${ }^{1}$
}

Carla Delgado de Piedade

Universidad de Lisboa

O presente texto pretende traçar a biografia do piloto português Sebastião Rodrigues Soromenho, na qual se destaca a viagem empreendida ao longo da costa da Califórnia, nos anos de 1594-1595, a mando de Filipe II, com o propósito expresso de descobrir pontos de apoio aos navios da rota de Manila. Ao empreender esta expedição, o navegador inscreveu o seu nome na lista de portugueses que serviram na armada castelhana e que contribuíram para a descoberta do Pacífico e o levantamento e registo das costas da América Hispânica, contribuindo de forma decisiva na definição das rotas do Pacífico no século XVI.

Para cumprir este propósito, debruçamo-nos na análise dos documentos relativos a esta expedição, como os dois roteiros, a documentação oficial emanada pelo rei e pelo vicereino de Nova Espanha e o traslado do testamento do piloto. Este conjunto de fontes tem permanecido até agora desconhecido da maioria dos estudiosos.

PalaVRas-chave: Soromenho, Califórnia, navegador, Portugal, Filipe II.

The purpose of this work is to describe the journey of the Portuguese navigator Sebastião Rodrigues Soromenho, who sailed along the shores of California at the command of Felipe II, in the years 1594-1595. His voyage was understood on the context of the participation of Portuguese navigators in the mapping of the Spanish American coast line, and their contribution for the definition of the maritime routes of the Pacific Ocean in the $16^{\text {th }}$ century.

To achieve our goal, we undertook a careful study of the documentation related to this expedition, namely the two itineraries, the oficial correspondence between the king and the vice-roys and the copy of the Soromenho's will. All of these documents have remained unknowed for the most of us.

KEYDWORDS: Cermeño, California, mariner, Portugal, Filipe II.

No contexto da expansão marítima dos reinos ibéricos, pese embora a legislação castelhana que interditava a presença de estrangeiros, e nomea-

1 Este artigo decorre da tese de mestrado apresentada na Faculdade de Letras da Universidade de Lisboa, em Julho de 2005, intitulada $O$ contributo português na definição das rotas do Pacífico: a viagem de Sebastião Rodrigues Soromenho, realizada sob orientação do Professor Doutor Francisco Contente Domingues. 
damente portugueses, não constituía novidade o trânsito de homens ligados à marinharia de Portugal para Castela. Podemos citar como exemplos Fernão de Magalhães, que liderou a primeira viagem de circum-navegação a mando dos Reis Católicos, e João Baptista Lavanha, cartógrafo contratado por Filipe II, em 1582, para ensinar na Academia de Madrid. A vontade de melhorar as suas condições de vida que impelia os homens do mar portugueses a atravessar a fronteira, encontrou resposta na necessidade nunca completamente suprida que Castela tinha por este tipo de profissionais. De entre tantos, iremos destacar o nome de Sebastião Rodrigues Soromenho, português, piloto-maior da Carreira das Filipinas e da China, que em 1595, recebe de Filipe II a missão de navegar ao longo da costa da Califórnia com o fim de proceder ao levantamento de portos de apoio aos navios da rota de Manila, descobrindo nessa viagem a baía de S. Francisco (actual baía Drake) e elaborando um roteiro detalhado da rota seguida, das terras que viu e dos índios com quem contactou. É através dele que vamos procurar traçar um quadro, ainda incompleto, da participação portuguesa na definição das rotas do Pacífico no século XVI.

Uma das preocupações dos homens que ocuparam o cargo de vice-rei da Nova Espanha, de António de Mendonza a Gaspar de Zuñiga, passando por Luís de Velasco, foi o domínio do Pacífico e o cotejamento dos seus limites terrestres. Nada mais sensato, pois como é amplamente sabido, este representava a plataforma sobre a qual assentava um dos principais veios de riqueza da coroa castelhana. A mesma preocupação tiveram os reis portugueses face ao Atlântico e ao Índico. Ambos eram impérios marítimos, assentes no transporte de mercadorias, cujo sucesso estava directamente dependente da sua capacidade de controlar as condições de navegação, procurando antecipar os desmandos da Natureza e a cobiça dos concorrentes.

\section{As fontes documentais}

As fontes disponíveis para obtenção de dados sobre Soromenho são: o traslado do seu testamento feito em 1602 na Cidade do México², o Derrotero y Relasión del descubrimento que hizo Sebastián Rodríguez Cermeño por hordem de Su Magestad dende las Philipinas hasta ysla de

2 Arquivo Municipal de Sesimbra (Portugal), Traslado do testamento de Sebastião Rodrigues Soromenho, feito na Cidade do México a 1 de Abril de 1602. [Em diante identificado pela sigla AMS] 
Çedros ${ }^{3}$ e Relación de lo sucidido, en el uiage que yo el capitán Sebastián Rodríguez Cermeno boy a hazer en lo tocante al descubrimiento del cabo Mendozino ${ }^{4}$. Ambos datados de 24 de Abril de 1596, o primeiro redigido por Pedro de Lugo, escrivão de bordo, e o segundo de autoria de Soromenho. Deste foi feito um duplicado com oito fólios, escritos de um lado e de outro na mesma data de Abril de $1596^{5}$. Os textos seguem a ordem cronológica, ainda que não haja entradas para cada um dos dias passados no mar. A estes documentos, acrescentamos um terceiro, Testemunhos de como se perdeu a nau San Agustin e Informação sobre a qualidade da terra ${ }^{6}$, recolhidos pelo mesmo escrivão junto do piloto português e alguns membros da tripulação entre 30 de Novembro e 9 de Dezembro de 1595, onde constam os depoimentos em primeiro lugar de Soromenho, respeitando o seu posto de capitão e piloto maior, seguindo-se os do alferes Juan del Rio, do sargento Juan Gutierrez, do marinheiro Domingo Francisco e por último, do piloto Juan de Morgana. O teor dos seus testemunhos é muito semelhante ao de Soromenho, obedecendo ao inquérito definido pelo escrivão. Pronunciando-se sobre o naufrágio e as medidas tomadas pelo capitão para ultrapassar a perda do navio e dos abastecimentos, foram depois inquiridos sobre a qualidade da terra e da sua população à luz de um plano de conquista e colonização. Este conjunto representa o núcleo duro, complementado com a documentação oficial castelhana ultramarina entre 1587 e 1596, que inclui o relato do saque ao galeão Santa Ana e a correspondência oficial entre o vice-reino da Nova Espanha e Madrid, que abarca os mandatos de Luís de Velasco (1590-1595) e do Conde de Monterrey (1595-1603). Neste contexto, a questão do descobrimento do cabo Mendocino mereceu particu-

3 AGI, Mexico, 23, N.5013, Derrotero y relasion del descubrimiento que hizo Sebastian Rodriguez Çermeño por horden de Su Magestad dende las Philipinas hasta ysla de Çedros, 24 abril 1596. Encontrámos duas transcrições do roteiro em Wagner, Henry R.: "The voyage to California of Sebastian Rodriguez Cermeño in 1595”, California Historical Society Quarterly, vol. III, n. ${ }^{\circ}$ 1, April 1924 (com tradução em inglês) e Mathes, Michael: Californiana I. Documentos para la transformación comercial de Califórnia. 1583-1632, Ediciones Jose Porrua Turanzas, Madrid, 1965.

4 AGI, Mexico, 23, N.50, Relacion de lo sucedido, en el uiage que yo el capitan Sebastian Rodriguez Cermeño boy a hazer en lo tocante al descubrimiento del cabo Mendozino, 24 Abril 1596. Por razões de mera funcionalidade, conforme explicitado na Introdução, designamos este documento por "Roteiro de Soromenho". Por questões meramente funcionais, optamos por designar o primeiro documento de "Derrotero de Pedro de Lugo" e o segundo de "roteiro de Sebastião Rodrigues Soromenho", obedecendo ao tratamento dado a pessoa Soromenho, designado na 3 . $^{\text {a }}$ pessoa ou na $1 .{ }^{\mathrm{a}}$ pessoa, respectivamente.

5 AGI, Mexico, 27, N. 18, Relacion de lo sucedido, en el uiage que yo el capitan Sebastian Rodriguez Cermeno boy a hazer en lo tocante al descubrimiento del cabo Mendozino, 24 Abril 1596.

6 AGI, Mexico, 23, N. 50\4, Testemunhos de como se perdeu a nau San Agustin e Informação sobre a qualidade da terra, 30 Novembro 1595. 
lar atenção. Discordando da opinião de Celestino Soares e Jorge Preto Guerra, que atribuem a descoberta a Soromenho, é nossa convicção que o mérito do feito pertence à expedição liderada por João Rodrigues Cabrilho.

A inteligência arguta de Vitorino Magalhães Godinho, permitiu afinar a nossa grelha de análise destes documentos, alertando-nos de forma gentil para a necessidade de estar atento aos silêncios das fontes descritivas dos primeiros encontros com o Novo Mundo e os seus habitantes ${ }^{7}$, que decorreriam não tanto de uma vontade arquitectada de tornar segredo como da incapacidade de assimilar e reproduzir em texto e imagens a grandeza da novidade, já que segundo o autor os descobridores enfrentaram a vertigem do espaço, cuja escala excede as suas expectativas e onde ainda não sabem situar-se, nem o sabem medir. Esta vertigem, à medida que as viagens prosseguem, irá ser substituída pela confiança no homem e na sua capacidade de senhorear o mundo inteiro ${ }^{8}$ de que os roteiros são um excelente exemplo. Através do cálculo de distâncias, rumos e ventos e da descrição minuciosa do visto e experimentado, os europeus vão redimensionando as terras descobertas a um conjunto de dados mensuráveis que conferem ao globo um tamanho inteligível e manuseável, avançado da descoberta para a conquista e daí para a colonização. $\mathrm{O}$ processo de assenhoramento não foi imediato, verificando-se uma persistência entre marinheiros, soldados e comerciantes da crença que os lugares míticos estão a um passo de serem alcançados. Tivemos assim viagens reais impulsionadas por fantasias. Pouco a pouco, a náutica irá purgar os seus textos destas referências, primando por um discurso quantitativo, de que os roteiros da viagem de Soromenho são um exemplo acabado. O piloto português praticou a navegação costeira, registando a data diariamente, a latitude a que se encontrava, descrevendo de forma minuciosa todos os acidentes da costa, as enseadas, surgidouros, recifes, ilhas e ilhotas, a paisagem, os contactos com as populações indígenas e as dificuldades da viagem. Nem podia ter sido de outra forma, basta ler o título - Derrotero e relaçion - é um roteiro e uma relação, ou seja, uma lista, um rol de dados informativos, construído légua a légua com o objectivo principal de permitir a qualquer piloto repisar o caminho, evitando acidentes e indo um pouco mais além. Não serve qualquer propósito incluir impressões pessoais ou alargar a descrição do que foi visto com frases floreadas e alusões

7 Godinho, Vitorino Magalhães: Mito e Mercadoria, Utopia e Prática de Navegar - séculos XIII-XVIII, Difel, Lisboa, 1990, pág. 58. Em particular no Capítulo III "Inovação e permanências nos séculos XV e XVI entre mito e utopia".

8 Godinho: Mito e Mercadoria, pág. 58. 
de recorte literário. Seria um desperdício de energia e de recursos e ambos são o maior capital de que dispõe cada indivíduo que embarca numa destas viagens ${ }^{9}$. Ambos são, no que respeita esta viagem, funcionários do rei a quem terão de prestar contas pela confiança neles depositada bem como pelo investimento económico. Afinal a sua missão era essa mesma, a de proceder ao reconhecimento da costa, continuando o levantamento iniciado antes dele por homens como Fernão de Magalhães, Pedro Unamuno e João Cabrilho, e imediatamente depois de si, por Sebastian Vizcaíno. De facto, basta folhear mesmo distraidamente os roteiros de Cabrilho e Vizcaíno para constatar tratar-se no essencial da mesma matriz, a que se acrescentaram ilustrações informativas do percurso no caso do roteiro de Vizcaíno. É um texto técnico, sem referências pessoais que permitam traçar um quadro biográfico do piloto português. As descrições das paisagens e da população nativa não recorrem a comparações com memórias passadas em Portugal ou nos locais que percorreu na sua carreira de piloto.

O estudo comparativo de roteiros portugueses e espanhóis pode ser um caminho frutuoso na investigação dos rumos da expansão marítima dos reinos ibéricos, se recordarmos o intercâmbio científico entre Portugal e Espanha naquela data. A fronteira institucional não se aplicava à marinharia e menos ainda em 1595-1596, data a que reporta o roteiro, com Portugal e Espanha unidos sob a mesma Coroa $^{10}$.

\section{A escolha do nome}

O apelido Soromenho é de origem portuguesa, mais certamente uma alcunha, talvez de proveniência geográfica. Um linhagista, digno de todo o crédito segundo a Enciclopédia Luso-Brasileira de Cultura, diz que a ori-

9 No caso dos pilotos portugueses, estes tinham de utilizar os documentos oficiais nas viagens e depois devolvê-los para não incorrerem em crime punido de forma severa (ver Daveau, Suzanne: "La géographie dans les "roteiros" portugais des XVe et XVIe siécles", Separata de Mare Liberum, Lisboa, 1991, pág. 161-181). O mesmo acontecia com os pilotos dos navios espanhóis, pois trata-se de impedir a divulgação de dados cruciais para a estratégia régia.

10 Isso mesmo afirmou Teixeira da Mota: "Seria, aliás, extremamente importante proceder a trabalho paralelo em relação a roteiros espanhóis, por duas razões: uma, devida à larga interpenetração das actividades marítimas dos dois povos, pelos esclarecimentos que daí poderiam obter-se em relação aos roteiros portugueses; a outra, a de proceder a análises comparativas, já que portugueses e espanhóis foram os dois povos a primeiro praticar navegação oceânica em larga escala, e é natural que tenham chegado a soluções semelhantes e que elas se traduzam nos roteiros.” Mota, Avelino Teixeira da,: Evolução dos roteiros portugueses, Lisboa, Junta de Investigações do Ultramar, 1969, pág. 32. 
gem provável do nome cabe a D. Brás Anhaia Galego Soromenho, que devia descender de D. Pedro Anhaia Maldonado Soromenho, que viera para Portugal no tempo de D. Afonso V, e casou com D. Maria Vabo Pimentel, de quem teve descendência que se radicou no Algarve. A grafia antiga de Seromenho, Sermenho e Cermenho foi bastante utilizada. A família veio para Portugal durante o reinado de D. Afonso V, fixando-se no Algarve e em Sesimbra. Deste ramo há a destacar, a par de Sebastião Rodrigues, João Soromenho de Carvalho, almirante da frota do Brasil, que se notabilizou, no século XVII, nas lutas contra os holandeses ${ }^{11}$.

Seromenho, Soromenho, Cermeño, Cermenon, Zermeño e Zermenyo são as diferentes formas de identificar o piloto português que encontramos até agora. O primeiro nome por uma vez foi tido como João ${ }^{12}$, sendo o apelido Rodrigues o que se manteve igual se mantivermos presente a substituição do "s" por "z" típica do castelhano. Há ainda a variante Sebastian Melendez Rodriguez utilizada no roteiro de Gerónimo Palácios da viagem de Viscainho de $1602^{13}$. Perante este cenário, a nossa escolha recaiu sobre a grafia "Soromenho" por razões de coerência na leitura e por ser aquela que se utiliza em Portugal, ainda que na documentação que sustenta a nossa análise, e que é na sua totalidade de produção castelhana, o nome tenha recebido um acento castelhano que o próprio aceitou, como está patente na assinatura do roteiro. Não se trata de uma questão pacífica, afinal trata-se do nome, da signatura, da marca que nos identifica em confronto com todos os outros. Foi uma decisão ponderada, hesitante por estar a vincar a nacionalidade portuguesa num contexto sócio-político que diversos nomes ilustres da historiografia afirmam estar marcado pelo trânsito fácil entre os reinos ibéricos, nos quais a origem não constituía um obstáculo inultrapassável para o exercício de um ofício, particularmente no que toca aqueles que versavam a ciência náutica, quer como estudiosos quer como homens do mar. Justificamos a nossa decisão com o facto de o nosso objecto de

11 As armas do brasão deste apelido são: de vermelho, Soromenho de verde perfilado a ouro, arrancado e frutificado de prata, e acompanhado em chefe, de uma flor-de-lis de oiro, no cantão dextro, de um crescente do mesmo sinistro, a que se acrescenta o timbre, um soromenho (árvore). Receberam cartas de brasão em 1759, 1774 e 1792. "SOROMENHO, Geneologia", Enciclopédia LusoBrasileira de Cultura, Editorial Verbo, Lisboa, 1975, vol. 17, pág. 561-562.

12 Maia, Carlos Roma Machado de Faria e: Prioridade dos Portugueses no descobrimento da América do Norte e ilhas da América Central. Considerações sobre um grande livro americano, Lisboa, Tipografia e Papelaria Carmona, 1931.

13 AGI, Mexico, 372, Derrotero desde Acapulco al Cabo Mendocino por Geronimo Martin Palacios con los disenos de la costa hechos por Enrico Martinez, 8 y 19 de Noviembre 1603. 
estudo ser português como expressivamente o declaram os desejos contidos no seu testamento, sabendo que podemos ser criticados por estar a incorrer num dos erros mais temidos da análise histórica, o anacronismo ${ }^{14}$.

\section{"Natural de Sesimbra e vizinho desta cidade do México"}

Traçar a biografia de Sebastião Rodrigues Soromenho foi um trabalho que exigiu alguma paciência e bastante perseverança. O seu caso não é inédito no contexto do século XVI, pois como é sobejamente sabido quando se trata desta época, qualquer texto desta natureza é, o mais das vezes, fruto de um coligir de retalhos de informação obtidos das mais variadas fontes e com espaços em branco. No caso presente, não nos foi ainda possível encontrar registos da sua vida em Portugal, como data de nascimento, filiação, estudos, se teria exercido qualquer actividade profissional como marinheiro ou outro e desde quando se encontrava nos mares da China como piloto. As informações de que dispomos resultam, nesta etapa da investigação, de textos historiográficos portugueses, como por exemplo, a breve entrada que consta da Enciclopédia Luso-Brasileira de Cultura e o texto de Celestino Soares, norte-americanos como os trabalhos de Henry Wagner e Robert Heizer, e espanhóis, como Sylvia Hilton e Juan Gil ${ }^{15}$, em cruzamento com a análise das fontes históricas, nomeadamente, o traslado do seu testamento disponível no Arquivo Municipal de Sesimbra, e a documentação oficial produzida pelas autoridades espanholas aquando do saque

14 Esta questão remete-nos para a função da História na construção da identidade de um país ou comunidade. No caso de Soromenho, e de forma mais notória com Cabrilho, a comunidade dos descendentes de portugueses radicados nos EUA encara-os como os elos que mantém viva a ligação à terra-mãe e que fornecem a explicação da presença portuguesa na Califórnia. São fundadores da LUSAlândia, conceito de Onésimo Teotónio de Almeida, para que San Payo nos remete logo na primeira página da sua obra. San Payo, Urbino, Os portugueses na Califórnia, Secretaria de Estado da Emigração, Porto, 1985. Ver também Dias, Eduardo Mayone (organização de), Portugueses na América do Norte, Peregrinação Publications, 1999.

15 Guerra, Jorge Preto: "Soromenho, Sebastião Rodrigues" in Enciclopédia Luso Brasileira de Cultura, vol.17, Editorial Verbo, Lisboa, 1975, págs. 562-3; Soares, Celestino: California and the portuguese, Lisboa, SPN Books, 1939; Monteiro, Rafael: Alguns mareantes desconhecidos da terra de Sesimbra e outros textos, Câmara Municipal de Sesimbra, Sesimbra, 2001; Wagner, Henry R.: "The voyage to California of Sebastian Rodriguez Cermeño in 1595", California Historical Society Quarterly, vol. III, n. ${ }^{\circ}$ 1, April 1924; Heizer, Robert Fleming: Archaeological Evidence of Sebastian Rodríguez Cermeño's California Visit in 1595, California Historical Society, San Francisco, 1942; Hilton, Sylvia L.: La Alta California Española, Editorial Mapfre, Madrid, 1992; Gil, Juan: Mitos y utopias del descubrimiento: el Pacífico, Alianza Editorial, Madrid, 1989. 
do galeão de Manila Santa Ana, em 1587, e da viagem ao longo da costa da Califórnia em 1595-96.

Um dos caminhos para a obtenção de dados biográficos sobre Soromenho reside na análise do traslado do seu testamento, que pode ser consultado no Arquivo Municipal de Sesimbra. O original foi escrito na Cidade do México a 11 de Fevereiro de 1602 (do qual foi feito o traslado de 1 Abril de 1602), poucos anos depois da sua viagem ao longo da costa da Califórnia, tendo tido por seu testamenteiro Diego de Paz, e assina o traslado o tabelião Juan de Vallejo ${ }^{16}$. O facto de ter sido feito o traslado do testamento para ser enviado para o Reino, indica que o piloto morreu no ano de 1602. Não temos a data precisa, mas podemos inferir que foi entre os meses de Fevereiro e Março, atendendo à data do testamento de 11 de Fevereiro e a do traslado de 1 de Abril. Da sua leitura ficamos a saber que Sebastião Rodrigues Soromenho nasceu em Sesimbra: a la Cassa de la Santa Misericordia de Cicinbra donde yo naci para el sustento de los pobres ${ }^{17}$. Mais informa que era casado com Beatriz Afonso, já que determina que seja a única herdeira de todos os seus bens, ou caso já tenha falecido, deve metade ser entregue à Casa da Misericórdia do hospital da cidade de Lagos e a outra metade à Misericórdia de Sesimbra ${ }^{18}$. Não são referidos quaisquer outros familiares, como filhos, irmãos, pai e mãe. A ligação a Lagos deve-se, segundo Jorge Preto ${ }^{19}$, ao facto de Beatriz Afonso ser natural dali. Acrescente-se que no testamento, Soromenho afirma:

16 A preocupação de Soromenho é típica dos homens desta época, como assinala Duby ao debruçar-se sobre o quadro mental europeu medieval. É a chamada "boa morte" relacionada com a ideia de que a pessoa devia ter uma morte vagarosa que lhe possibilitasse colocar em ordem os assuntos terrenos e arrepender-se dos pecados e com isso conseguir que a alma ficasse o menor tempo possível no Purgatório. O testamento do Soromenho reflecte essa preocupação. Duby, Georges: A Europa na Idade Média, Lisboa, Teorema, 1984, pág. 233-256.

17 AMS, Traslado do testamento de Sebastião Rodrigues Soromenho, f. 5.

18 A Santa Casa da Misericórdia foi criada a 15 de Agosto de 1498 por iniciativa da rainha D. Leonor com o estrito propósito de cumprir todas as obras de misericórdia corporais e espirituais. Não demorou muito a disseminar-se pelo país e nos territórios de África, Índia e Brasil, chegando mesmo à China. Em Portugal chegou a contar com 230 casas em apenas dois séculos, entre elas a Santa Casa da Misericórdia de Lagos e a de Sesimbra, duas das mais antigas, datando a primeira do ano inaugural de 1498 ( 2 de Julho) e a segunda do século XVI, não sendo possível precisar o ano. À data em que Soromenho dita as suas vontades, as duas casas já tinham celebrado o primeiro centenário e fincado o seu lugar na lista de herdeiros das doações dos portugueses que estivessem no reino ou a muitos quilómetros de distância.

19 Preto, Jorge, "Soromenho, Sebastião Rodrigues" in Enciclopédia Luso Brasileira de Cultura, Lisboa, Editorial Verbo, 1975,vol.17, pág. 562-3. 
yo Sebastiam Rodriguez Cermeño piloto mayor de la Carrera de las Yndias e China vezino desta ziudade de Mexico e natural de la ziudade de $\operatorname{Lagos}^{20}$.

Vemos aqui que Soromenho assume Sesimbra e Lagos como locais de naturalidade. No nosso entender, há uma distinção significativa que resolve as dúvidas: Sesimbra é o lugar onde nasceu e Lagos o lugar de onde é natural. O facto de a família ao chegar a Portugal se ter fixado em Sesimbra e no Algarve pode explicar esta duplicidade, permitindo-nos colocar a hipótese de que Soromenho pode ter passado parte significativa da sua infância e juventude em Lagos, a que se junta o casamento com Beatriz Afonso $^{21}$.

Ao que sabemos, Soromenho estava fora de Portugal há cerca de vinte anos, todavia o conteúdo do testamento declara que os laços afectivos com a terra natal e a mulher não foram quebrados. $\mathrm{O}$ piloto poderia ter constituído outra família apesar do casamento com Beatriz Afonso, ou mesmo que não o tivesse feito, o tempo e a distância tornariam compreensível que o remetesse para o silêncio; os bens que deixou à Misericórdia podia com mais facilidade entregá-los a uma instituição religiosa da Cidade do México ou à Misericórdia de Manila, fundada em 1594 segundo o modelo português. A leitura de Russel-Wood aponta o desejo de apaziguamento como razão que sustenta este esforço último de quem se sabe longe e sem possibilidade de regressar, de fechar o círculo da vida unindo as pontas do nascimento e morte. A escolha da Santa Casa da Misericórdia, segundo o mesmo autor, enquadra-se no conjunto de três medidas que a Coroa portuguesa implementou para garantir a manutenção da identidade portuguesa entre os seus vassalos espalhados pelos novos territórios ${ }^{22}$.

Contávamos encontrar mais informações biográficas sobre o piloto português nos documentos produzidos aquando da viagem às costas da Califórnia, o que não se veio a verificar. Esperávamos que ao descrever a paisagem, a fauna e flora fossem feitas associações por semelhança a Portugal ou a Sesimbra. Nos testemunhos recolhidos junto do capitão e alguns membros da tripulação entre 30 de Novembro e 8 de Dezembro de 1595 por Pedro de Lugo sobre o naufrágio e a qualidade da terra descober-

20 AMS, Traslado do testamento..., f.4.

21 A este propósito veja-se o relato de António di Serra sobre o saque do galeão Santa Ana referido na nota 19.

22 Russel-Wood, A.J.R.: "Os portugueses fora do Império", en Bethencourt, Francisco e Chaudhuri, Kirti (directores), História da Expansão Portuguesa, Círculo de Leitores, Lisboa, 1998, vol. 2., págs. 256-265. 
ta, a cada um dos declarantes foi perguntada a idade e pedido que assinasse o seu testemunho. A cada um, excepto infelizmente ao primeiro a ser chamado que foi naturalmente o capitão. Dele ficamos apenas a saber que sabe assinar, o que faz usando a grafia "Sebastian Rodriguez Sermeño".

\section{Soromenho e o saque do galeão Santa Ana}

Uma das informações mais recuadas de que dispomos sobre Soromenho data de 1587, ano em que o corsário Thomas Cavendish saqueou o galeão de Manila Santa Ana, de cuja tripulação fazia parte o piloto português. É possível confrontar o modo como ingleses e espanhóis vivenciaram o acontecimento, através dos relatos feitos na época pelas duas partes; de um lado, os relatórios feitos pelo comandante do navio, Tomás de Alzola, e um passageiro, António di Serra, às autoridades régias, e do outro a navarrativa da viagem de Thomas Cavendish que consta da colecção documental reunida por Richard Hakluyt ${ }^{23}$. A estas narrativas, acrescentou-se, em 1593, os testemunhos de mais três súbditos espanhóis chamados pela audiência do México a prestar declarações sobre um pormenor em particular relacionado com o saque.

Nas negociações que se seguiram à rendição espanhola, Tomás Alzola fez-se representar por Pedro Bravo de Paredes. Levado a bordo do Desire, pouco depois outros se lhe juntaram: o capitão, o frade Francisco Ramos, Don Juan de Almendrales, Antonio de Sierra, Juan Baldonado e, segundo o relato de António Serra, o português Sebastião Rodrigues Soromenho. No dia seguinte, o Santa Ana foi levado até terra para fazer desembarcar os passageiros e tripulação, juntamente com trinta outros espanhóis feitos reféns de Cavendish em ataques anteriores. É a partir deste momento que a acção de Sebastião Rodrigues Soromenho se notabiliza, contribuindo de forma decisiva para o resgate da nau e regresso dos passageiros a Nova Espanha.

23 AGI, Patronato, 265, R.51, Copia de la confission que hizo el capitan Thomas de Alçola Maestre de la nao sanctana que rouaron los yngleses en el cauo de San Luca,15 de Janeiro de 1588; AGI, Patronato, 265, R. 51, Declaration de Antonio de Sierra sobre la perdida del navio Santa Ana, Guadalajara, 24 de Janeiro 1588.Quanto à versão inglesa, leia-se "The prosperous voyage of M. Thomas Candish esquire into the South sea, and so round about the circumference of the whole earth, begun in the yere 1586 and finished 1588", Richard Hakluyt, The Principal Navigations, Voyages, Traffiques \& Discoveries of the English Nation, James MacLehose and Sons, Glasgow, 1904, vol. XI, ppág. 290-347. (O relato encontra-se entre as páginas 324-327 e 331-332.) 
A descrição que apresentámos baseia-se na análise dos relatos feitos sobre o acontecimento, referidos acima. Coincidindo ambos na violência do confronto, e na superioridade bélica inglesa, Tomas de Arzola e António di Serra, diferenciam a sua narrativa precisamente no ponto que a nós mais interessa, ou seja, a identificação do piloto. Segundo o testemunho do capitão do Santa Ana, o corsário inglês assim que soube que tinha vencido, fêlo vir a bordo acompanhado do escrivão e do piloto, cujo nome não indica. Mais tarde, quando se prepara para partir, Cavendish necessita de pilotos capazes de o colocar nas águas das Filipinas em meados de Fevereiro impreterivelmente, para poder seguir em direcção ao cabo da Boa Esperança. Para isso, torna cativos dois espanhóis e um português:

Y que para el dicho efecto lleuaron dos españoles que tomaron de la dicha nao Sanctana platicos llamados Alonzo de Valladolid y Nicolau Rodrigues, portugues ${ }^{24}$.

Confrontando com o pormenorizado relato de Thomas Cavendish, os nomes dos homens capturados e levados a bordo coincidem, assim como na ausência de qualquer menção a Soromenho. Tudo o que é dito é que o capitão e o seu piloto foram trazidos a bordo, e que tendo apresentado o rol de riquezas que o galeão transportava ficou decidido que permaneceriam no navio, sem, no entanto, os identificar. Dias mais tarde, a 17 de Novembro, o capitão foi dispensado com provisões para se defender dos índios, duas espadas, armas e pólvora. Porém antes de partir, foi retirado do Santa Ana um grupo de sete pessoas constituído por Cristóvão e Cosmus, dois jovens do Japão tidos como muito capazes sabendo ler e escrever japonês ambos com cerca de 17 anos, três rapazes nascidos em Manila, Afonso com 15, António de Dasi de 13 e o mais novo com 9 anos, Tomás de Ersola, piloto espanhol experiente na rota entre Acapulco e as Filipinas e um português Nicolau Rodrigo descrito como:

one Nicholas Roderigo a Portugall, who hath not onely bene in Canton and other parts of China, but also in the islands of Japon being a countrey most rich in silver mynes, and hath also bene in the Philippinas. ${ }^{25}$.

Comparando as duas listas, verificamos que os nomes dos jovens coincidem, e que piloto autor da carta, Tomas Erzola, na versão espanhola foi Alonzo de Valladolid. É certo que o apelido é o mesmo, e no seu testa-

24 AGI, Patronato, R. 51\2\9.

25 Hakluyt, Richard: The Principal Navigations, pág. 327. 
mento Soromenho indica ter estado na China e Filipinas, mas Rodrigues é um nome muito vulgar, de Sebastião para Nicolau vai uma grande distância, e encontrar portugueses nos mares da China e Filipinas não era fora do comum.

A presença do piloto de Sesimbra nestes acontecimentos foi certificada de modo inequívoco às autoridades da Nova Espanha, através do relato de António di Serra:

Salimos del puerto de Cabite que es puerto de la çuidade de Manilla credera del señor San Pedro deste año proximo pasado de mill y quinhentos y ochenta y siete en que venia por capitan un vizcayno llamado Tomas de Arçola y por piloto Sebastian Rodrigues Portugues algarauio. ${ }^{26}$

Quando cerca de cinco anos mais tarde, o vice-rei Luis Velasco se prepara para retomar a empresa de descobrimento e exploração da costa californiana, prosseguindo o esforço de um seu antecessor António de Mendoza, as qualidades profissionais de Soromenho tornam-no num candidato. Certamente conhecedor das informações prestadas anos antes por Tomás Arzola e António di Serra, num gesto cauteloso e próprio de um alto funcionário régio, Velasco ordenou o inquérito com vista a averiguar do comportamento de Soromenho aquando do saque do galeão. A memória desse grave revés é, no mínimo, difícil de gerir e todos os cuidados são poucos. O inquérito começou a ser preparado a 14 de Junho de 1593, sob responsabilidade dos provedores da real audiência de Nova Espanha, nomeadamente, o doutor Santiago del Riego, tendo sido chamados três vizinhos da cidade do México e os seus depoimentos registados pelo escrivão Pedro Sanches Moreno ${ }^{27}$.

A primeira testemunha foi ouvida a 20 do mesmo mês e chamava-se Diego Montoro, mercador, de cinquenta anos de idade. Quando perguntado há quanto tempo conhecia Soromenho, diz que há mais de onze anos ${ }^{28}$, o que nos permite balizar há quanto tempo Sebastião Rodrigues Soromenho era piloto nas Filipinas. Num cálculo simples, ficamos a saber que pelo menos desde 1582 que exercia o cargo de piloto na carreira das Índias Ocidentais, já que das três testemunhas esta é aquela que declara

26 AGI, Patronato, 265, R. 51\1\2.

27 AGI, Mexico, 221, N 2, Informação sobre os méritos de Sebastião Rodriges Soromenho, Audiência da Nova Espanha, 14 de Junho de 1593.

28 AGI, Mexico, 221, N 2 , ff. 1 e 2. 
conhecer o piloto português há mais tempo. As outras duas testemunhas chamadas a comparecer diante dos oficiais da audiência foram Juan de Balesteros, de dezanove anos, que estava ao serviço de Santos Garcia, bispo de Galiza; e Pedro de Ribera, de vinte e um anos, morador na cidade do México, de profissão "tirador de oro". O testemunho deste último corrobora a data de 1582 que apresentamos atrás, ao colocar Soromenho como piloto maior da armada que levou Santiago de Vera para as Filipinas para exercer o cargo de presidente da Real Audiência, instituída por decreto de 5 de Maio de $1583^{29}$.

Estabelecida a identidade das testemunhas, o inquérito prossegue obedecendo a um conjunto de questões pré-determinado, igual para todos eles: se a testemunha vinha a bordo do Santa Ana aquando do ataque do corsário inglês; se o piloto português também ia a bordo e se tinha tido alguma culpa no sucedido; se o inglês o tinha querido levar consigo; se se defendeu dessa intenção; se ajudou de alguma forma na reparação do galeão e na chegada ao porto de Acapulco fazendo serviço a Sua Majestade, sendo por isso merecedor da mercê que Filipe II tem intenção de lhe dar. As três testemunhas são unânimes em afirmar que o piloto português se escondeu para escapar do manifesto intento de Thomas Cavendish de o levar consigo e que tendo logrado no seu intento, reapareceu para ajudar na reparação dos destroços queimados do Santa Ana e na sua condução até ao porto de Acapulco. Elogiosos, enaltecem as suas qualidades profissionais e consideram-se-lhe devedores das suas vidas, e portanto subscritores de qualquer mercê que a Coroa lhe queira fazer.

Com base na narrativa, conseguimos compreender a necessidade de Velasco saber até onde o português colaborou com Thomas Cavendish, ainda que coagido. A intenção do corsário inglês em levá-la foi clara para os passageiros do Santa Ana, e de tal forma vigorosa que o piloto português teve de recorrer à dissimulação para conseguir escapar. Por outro lado, António di Serra identificou-o e Tomas de Arzola diz que o piloto foi com ele a bordo, sem explicar qual foi o seu destino, se ficou a bordo ou regressou. Curiosamente, cinco séculos mais tarde, os testemunhos que apaziguaram os temores do vice-rei, e através dele, Filipe II, não abalam a convicção de alguns autores ${ }^{30}$ de que Soromenho tinha sido um dos pilotos que

29 AGI, Mexico, 221, N 2, f. 5.

30 Um desses autores é Hector Santos, "The sacking of the galleon Santa Ana", Sulat sa Tansô ,US, April 5, 1997. http://www.bibingka.com/sst/santana/santana.htm. Por efeito de repetição, outros textos na Internet defendem a mesma ideia. 
Thomas Cavendish fez refém para conseguir atravessar os dois oceanos que o separavam da relativa segurança do Atlântico.

\section{A atribuição do hábito de Cristo a pilotos}

A pertinência deste documento não se esgota na questão relativa à actuação do piloto face ao intento de Cavendish o utilizar. Através dele ficamos também a saber que mercê Filipe II estava preparado a fazer se fosse bem sucedido na viagem ao cabo Mendocino:

Preguntado si siendo Su Magestad seruido de hazer $\left[4^{\circ}\right]$ al dicho piloto mayor la merçed que pretende de que con el dicho ofiçio se le de el salario hordinario asi de el tienpo que ouiere de nauegar como no nabegando y de el auito de Cristo como se acostunbra en Portugal. ${ }^{3 l}$

Como se infere deste excerto, Soromenho seria devidamente recompensado pelo seu esforço num gesto régio que traduz o reconhecimento da nacionalidade do piloto, aqui tida como uma mais-valia.

A concessão de mercês aos pilotos nos séculos XV e XVI era de facto frequente, conforme nos indica José Frazão de Vasconcelos ${ }^{32}$. Para consubstanciar esta ideia enumera numa lista de catorze nomes, os pilotos que receberam mercês régias nesse período, indicando haver muitos mais numa prova cabal que os seus serviços e os seus conhecimentos técnicos eram publicamente reconhecidos pela Coroa, refutando no mesmo passo a noção expressa por vários historiadores do século XIX que tal apreço só cobria os nobres no exercício das funções de capitão do navio. Para o autor, no século XVII torna-se mesmo "normal" a Coroa recompensar os pilotos e outros ligados aos assuntos da navegação com a entrada nas ordens militares de Santiago e principalmente Avis (o autor não inclui a Ordem de Cristo), fechando os olhos aos impedimentos revelados pelas provanças como o dos pais ou avós terem exercido ofícios mecânicos. Uma vez aceites, estes pilotos iniciavam um caminho de nobilitação, desfrutado do foro de escudeiro e cavaleiro, e tendo muitos instituído morgados e capelas. Felipe III, numa consulta da Mesa do Desembargo do Paço

31 AGI, Mexico, 221, N 2, ff. 4 e 5.

32 Vasconcelos, José Frazão de: Os pilotos dos séculos XV e XVI e a nobreza do reino, Separata da revista História, Lisboa, 1932. 
a 20 de Agosto de 1625 decreta "que se não reputem mecanicos os filhos de Pilotos, Mestres e Oficiais da Marinha." ${ }^{33}$.

A Ordem de Cristo, inicialmente vocacionada para a luta contra o Infiel, foi-se moldando ao quadro político criado pela expansão ultramarina, no qual desempenhou um papel de suma importância. De facto, a partir do ano de 1495, quando com D. Manuel o rei passa a ser o governador e administrador perpétuo da ordem, esta é encarada como um meio para recompensar aqueles que prestaram serviços à Coroa, multiplicando-se o número de comendas. A ilustrar a utilização que a Coroa castelhana fez deste precioso instrumento político, existe uma lista de cavaleiros da Ordem de Cristo que cobre as datas de 1579 a início de 1631, contendo 2,265 nomes, dos quais 1,240 entre 1579 e 1598. Destes ressalve-se que 1,097 dos novos membros foi durante o período de Filipe $\mathrm{II}^{34}$.

De facto, Filipe II teve uma clara consciência do valor que a outorga do título de cavaleiro de Cristo encerrava. A morte de muitos nobres portugueses na batalha de Alcacér Quibir deixara espaço para novos membros que foram escolhidos entre aqueles que o Cardeal D. Henrique e Filipe II protegiam, especialmente Filipe II que nos primeiros quatro anos fez 588 cavaleiros. Mantendo a linha definida por D. Sebastião, o monarca beneficiou em maior percentagem os que serviram no Norte de África (Tânger, Mazagão e Ceuta), seguindo-se os que se encontravam na Índia e em número significativamente menor os que estavam no Brasil, não se esquecendo daqueles que integravam as Armadas do Reino. E claro, os que manifestaram a sua lealdade aquando da sua campanha pelo trono de Portugal. Deu o hábito a oficiais da justiça, tanto juízes da relação do Porto e da Índia como oficiais mais abaixo na hierarquia (juízes de fora e corregedores). Os Duques de Bragança, como D. João, não foram negligenciados, como também não o foram aqueles que lhe estavam mais próximo, os seus conselheiros, secretários e os seus filhos e membros da casa do rei. Face a estas escolhas, podemos dizer que o monarca espanhol politizou a entrada na ordem, como afirma Francis Dutra, subscrevendo uma leitura

33 Vasconcelos, Frazão de: "Os pilotos dos séculos XV e XVI e a nobreza do reino”., ppág. 10-11. Em nota de rodapé:"Liv. ${ }^{\circ} .^{\circ}$ do Desembargo do Paço, fl 66, conforme citação de João Pedro Ribeiro, no Indice Chronologico, vol. I, pág.77."

34 Referimo-nos à Lista dos Cavalleiros da Ordem de Christo tirada do Livro da Matricula q esta no Convento de Thomae, Cabela e Ballia da dita Ordem, per sua ancianidade, começando desde o tempo del Rey Dom Henrique em diante, pertencente à Biblioteca Nacional de Madrid. 
da função da Ordem partilhada por outros antes dele, como D. Manuel, por exemplo ${ }^{35}$.

Serve este breve apanhado sobre a Ordem de Cristo para melhor dar a compreender o significado que a mercê que Filipe II demonstra estar disposto a fazer terá tido para Soromenho. Talvez assim se entenda o empenho evidenciado ao longo da viagem, a forma firme, temperada com palavras de ânimo, como recusou os pedidos da tripulação e passageiros para que rumasse direito a algum porto conhecido. Receber o hábito de Cristo equivalia ao reconhecimento da sua mestria profissional, a consagração perante os seus pares. No que diz respeito a Filipe II, o seu gesto é por nós interpretado por um lado, como o sinal visível da importância que o prosseguimento da exploração e registo cartográfico da costa do Pacífico tinha para a consolidação do império ultramarino, nomeadamente da rota de Manila; e por outro, revela conhecer o lugar que a Ordem de Cristo ocupava na sociedade portuguesa e a sua função na fidelização dos súbditos ao rei. Filipe II podia ser rei de Portugal, mas era castelhano e Soromenho, português.

\section{A contratação de Soromenho à luz da legislação castelhana}

Em 1594, o navegador é piloto das carreiras da Índia e da China sob as ordens do rei Filipe II de Espanha e I de Portugal graças à união das coroas de Portugal e Espanha celebrada nas Cortes de Tomar de Abril de 1581. E assim teria continuado se o rei não tivesse aceite a recomendação do vice-rei do México, Luis de Velasco, que cumpria o seu primeiro mandato iniciado em 1590 (Velasco regressaria ao cargo entre 1607 e 1611 com o título de Marquês de Salinas, em reconhecimento das suas capacidades). Este apresentou-o como um piloto competente e capaz de cumprir com o arrojado empreendimento de proceder ao reconhecimento da costa da Califórnia, com o objectivo de descobrir um porto de apoio dos navios provenientes de Manila, onde pudessem proceder a reparações e abasteceremse de água e mantimentos frescos:

35 Dutra, Francis: Membership in the Order of Christ in the Sixteenth Century: Problems and Perspectives, Santa Barbara Portuguese Studies I, 1994. (Este artigo pertence a um estudo mais alargado das ordens militares de Cristo, Avis e Santiago entre 1500-1570, datado de 1971-1974. O autor tem também um artigo sobre o século XVII "Membership in the Order of Christ in the Seventeenth Century:Its Rights, Privileges and Obligations” in The Americas, 27:1, July 1970, pág. 3-25.) 
Por un capitulo de carta que vuestra magestad mandó escrivirme a 17 de henero de 1593 manda que descubran y demarquen los puertos del viaje destas yslas para seguridad de las naos que ban e vienen y supuesto que para hacerlo hera menester navio y dinero, ó a lo menos permitir a la gente alguna inteligencia ó negociacion de las que vuestra magestad tiene prohibidas en que pudiesen ser aprovechados conforme a su trabajo [...] y ordene al piloto que agora ba en la capitana que se llama Sebastian Rodriguez Cermeño, y es hombre platico en la carrera, seguro y que tiene posible, aunque portugues porque no los ay deste officio castellanos, que haga el descubrimiento y demarcacion $[\ldots]^{36}$

Apenas uma compreensível condição: que as contrapartidas económicas fossem vantajosas, isto é, que Soromenho fosse autorizado levar moeda para comerciar nos portos que descobrisse ao longo da costa. De facto, Luis de Velasco já havia chamado à atenção do rei para a falta do dinheiro necessário para proceder ao descobrimento dos portos de apoio da rota de Manila. Porém, numa demonstração de competência, informou, nessa mesma carta de 8 de Outubro de 1593, saber de gente que estava disponível para aceitar a empreitada. ${ }^{37}$

Luis de Velasco não podia deixar de chamar a atenção para a nacionalidade de Soromenho. Não se tratava de um pormenor de somenos importância se atendermos às várias disposições régias sobre o assunto. Dos critérios sobre quem podia exercer o cargo de piloto maior, um se destacava: a proibição a estrangeiros. O recrutamento devia ser feito dentro de fronteiras, com preferência para os naturais de Castela, Aragão e Navarra. Esta proibição estendia-se a outros cargos, como pilotos e mestres de navios e o motivo como facilmente se conclui era o de salvaguardar qualquer fuga de informação. No século XVI como hoje, o poder pertence ao detentor de informação privilegiada. É possível identificar uma dupla preocupação da coroa espanhola, que por um lado publica abundante legislação sobre a proibição de estrangeiros a cargos que implicavam o conhecimento das rotas e por outro fornece os meios para a concretização de um projecto de

36 "Capitulo de una carta del Virey de la Nueva España Don Luis de Velasco á S.M. fecha en Mexico a 6 Abril de 1594 referente a cargar á Sebastian Rodriguez Cermeño el reconocimiento de las costas de la mar del sur segun lo dispuesto por su magestad", Cutter, Donald C.: The California Coast. A Bilingual Edition of Documents from the Sutro Collectio transled and edited in 1891 by George Butler Griffi, University of Oklahoma Press, 1969, págs. 27-28.

37 "Capitulo de una carta del Virey de Nueva España Don Luis de Velasco, á S.M. diciendole que para hacer el descubrimiento de los puertos de la tierra firme hay falta de dinero; pero que existen personas que lo hagan por su cuenta mediante ciertas concesiones, fecha em Megico á 8 de Octubre de 1593”, Documents from de Sutro Collection, págs. 42-43. À margem pode ler-se: “ hagase la cedula que en tiempo se ha dado". 
formação técnica para os homens do mar. Porém esta intenção régia nunca pode ser aplicada com o rigor pretendido devido à escassez crónica de pilotos resultante de contingências diversas como os elevados salários exigidos por eles $^{38}$ até à difícil situação enfrentada pela construção naval. Carlos I procurou uma solução de compromisso expressa na Real Cédula de 11 de Dezembro de 1534, em que autoriza a Casa de la Contratación e a Juan Caboto, que na altura ocupava o posto de piloto maior, a admitir pilotos estrangeiros, solteiros e casados, desde que tivessem vivido em Espanha até à data e sem qualquer limitação se residissem em qualquer lugar do reino de Castela.

Assim quando ao lermos o roteiro de 1596 e depois o traslado nos quais Sebastião Soromenho é descrito com o título de capitão e de piloto maior da Carreira das Índias e do mar da China, estamos perante uma realidade que se encaixa perfeitamente no contexto das contradições vividas pela organização naval espanhola do século $\mathrm{XVI}^{39}$. Luis Velasco confirma isso mesmo na sua carta de 6 de Abril de 1594 dirigida a Felipe II, em que justifica a contratação do português apesar das leis que o proibiam por ter prática e não haver navegadores espanhóis com os conhecimentos necessários para empreender a viagem. Note-se que Velasco escreve nos últimos anos do século XVI, em 1594, oitenta e seis anos depois da criação do car-

38 Em 1536, o presidente da Casa de la Contratación, o licenciado Carbajal, queixava-se no Conselho da Índias dos honorários exorbitantes exigidos por pilotos e mestres, que fixavam o seu valor num salário fixo de 300 ducados, quando não mais. Até aquela data, a paga era de um ducado e meio a dois ducados. Para Carbajal o tecto salarial não devia ultrapassar 4 ou 5 soldadas para los pilotos e 2,5 a 3 para os mestres, acrescidas de despesas de manutencão." Segundo Bordejé y Morencos, esta falta de recursos financeiros levou ao afastamento dos aragoneses dos descobrimentos, importantes pelos seu saber naútico. Bordejé y Morencos, Fernando de: Tráfico de Indias y Política Oceánica, Editoral Mapfre, Madrid, 1992, pág.27.

39 Como explica Maria Guerrero no seu artigo: En ocasiones no era posible compaginar los buenos deseos com la realidad, y así, para paliar la escasez de pilotos nacionales preparados se autorizaba la navegación a personas no examinadas, a las que únicamente de una forma profisional - se les exigía que fuesen hábiles y suficientes. En otras ocasiones, la excepcionalidad venia a autorizar el embarco a marineros extranjeros, ante la falta de naturales que cubriesen todos los puestos disponibles en los barcos que participaban en la Flota de Tierra Firme o en la de la Nueva España. Eso sí, habían de ser católicos y no pertenencer - según el momento histórico - a las naciones consideradas enemigas. Los franceses e ingleses solían ser los más rechazados, mientras que los italianos fueron los preferidos. Leon Guerrero, Maria Montserrat: "Los descubrimientos cartográficos del viaje de Legazpi”, pág 131. Este e outros artigos sobre a temática, como o de Marta Milagros Del Vas e Miguel Luque Talaván, "Pilotos mayores, pilotos y maestres de navíos en las leyes de Índias de la época de Carlos I y Felipe II y su proyección en la recopilación de 1680" constam do seguinte título: Cuesta Domingo, Mariano (coord.): Descubrimientos y cartografía en la época de Felipe II. Valladolid: Seminario Iberoamericano de Descubrimientos y cartografia/ Instituto Interuniversitario de Estudos de Iberoamérica y Portugal/ Ayuntamiento de Valladolid, 1999. 
go de "piloto mayor" e quarenta e dois anos depois da entrada em funcionamento da "Cátedra de Navegacíon y Cosmografia"

Foi esta fissura da lei ditada pelas contingências que serviu o vice-rei Luis de Velasco. Mas esta moldura legal só se encaixa no quadro da viagem de 1594. Ora, a acreditar nos testemunhos dados pelos vizinhos de Soromenho na cidade do México no ano anterior perante a audiência real, e não temos razões para não o fazer, o piloto português exercia a sua profissão a bordo de navios espanhóis desde 1582, quando estava em vigor a Cédula de Julho de 1579. Nesta etapa do nosso raciocínio sublinhamos um acontecimento que marcou uma alteração de conjuntura: a União Ibérica. Quando em 1580 Filipe II inicia a Monarquia Dual, estava bem ciente da mais-valia técnica que daí advinha. A partir desse momento, cessava a necessidade de captar de forma dissimulada astronómos, cartógrafos e outros especialistas da arte de navegar. A contratação de João Baptista Lavanha, em 1582, para professor de uma academia de matemática em Madrid, é disso um exemplo paradigmático ${ }^{41}$. Reconhecido pela sua competência, iria servir o rei na sua intenção de colmatar a insuficiente preparação dos pilotos, que apesar de todos os esforços, como a criação do cargo de piloto maior, era por demais evidente. Para além de Lavanha, Filipe II assegurou os serviços do cartógrafo português Luís Jorge Barbuda. Como é sabido, a União Ibérica não correspondeu à integração das populações e territórios portugueses nas fronteiras espanholas, mas ainda assim traduziu-se numa aproximação e flexibilização no que dizia respeito às áreas de exclusividade portuguesa e castelhana. Este facto, somado à constante falta de pilotos, possibilitou o ingresso de Sebastião Rodrigues Soromenho. Às razões apresentadas acrescenta-se mais uma, a da existência de um fluxo de emigração de portugueses ligados ao mar para Castela, a par da vinda de espanhóis para Portugal, demonstrando a disparidade entre o que é determinação institucional expressa na legislação e a vivência quotidiana dos súbditos.

40 O cargo de piloto maior encontra-se explicado com minúcia na obra de Jose Pulido Rubio, intitulada precisamente El Piloto Mayor. Pilotos mayores, catedraticos de cosmografia y cosmografos de la Casa de la Contratacion de Sevilla, Escuela de Estudios Hispano-Americanos/Consejo Superior de Investigaciones Cientificas, Sevilla, 1950.

41 A importância da ciência naútica portuguesa para Castela, neste caso particular personificada por João Baptista Lavanha, tem sido estudada por Francisco Contente Domingues, nomeadamente na obra Os Navios do Mar Oceano. Teoria e empiria na arquitectura naval portuguesa dos séculos XVI e XVII, Centro de História da Universidade de Lisboa, Lisboa, 2004. 


\section{Na rota de Soromenho}

Acordados os termos do contrato por ambas as partes, Sebastião Rodrigues Soromenho larga de Acapulco a 21 de Março de 1594, a bordo do San Pedro, chegando a Manila no mês de Junho. Aqui devido ao mau estado em que se encontrava o navio que devia levar na viagem, foi aceite a proposta de Pedro Sarmiento de fornecer o San Agustin de sua propriedade, em troca da autorização em carregá-lo com bens para fazer comércio. Entre o final do ano de 1594 e os primeiros meses de 1595 foram feitos os preparativos da viagem.

A figura de Pedro Sarmiento representa a solução recorrente de permitir a participação de particulares como meio de obviar à dificuldade em reunir os fundos necessários através do erário público, política que foi seguida quer por Espanha quer por Portugal por diversas vezes no quadro da expansão marítima e exploração económica dos recursos ultramarinos ${ }^{42}$. Em Maio de 1609, a sua viúva, D. Elvira Davalos Y Sandoval, através de um requerimento apresentado às autoridades régias ilustra bem a dimensão do investimento feito pelo capitão Pedro Sarmiento:

vii. Si sauen que gouernando estas yslas don Luis Perez Dasmarinas tubo horden del rey nuestro señor para descubrir el cauo Mendoçino a costa de su Real auer. Y por estar presçintada la caxa asento y trato con el dicho capitan Pedro Sarmiento hiziese este descubrimiento el qual lo açeto y en esta conformidad armo un navio llamado San Augustin y de porte de duzientas toneladas poco mas o menos y lo abasteçio de armas muniçiones matalotajes y el salario marineros y piloto y gente de guerra y lo enbio al descubrimiento del dicho cauo Mendoçino. Y por culpa del piloto se perdió en la costa de la Nueva España sin que se escapase del mas que la gente. Y el dicho capitan Pedro Sarmiento en esta perdida perdio mas de cinquenta mill pesos. ${ }^{43}$

É um valor considerável, mesmo descontando um compreensível exagero por parte de D. Elvira, certamente conhecedora da contenção com que a Coroa atribuía as mercês. Segundo o rol apresentado, o capitão Pedro

42 Sobre a participação do armador Pedro Sarmiento veja-se Gil, Juan: Mitos y utopias del descubrimiento: el Pacífico, Alianza Editorial, Madrid, 1989, págs. 132-133.

43 AGI, Patronato, 52, R. 15, f. 3 e 3 verso, Informaciones echa de ofiçio contra la que hizo de parte don Joan Sarmiento de los merítos y seruiçios del capitan Pedro Sarmiento su padre, Manila, 5 de Maio de 1609. Ao descrever os méritos do seu falecido marido, D. Elvira informa-nos que Pedro Sarmiento chegou às Filipinas com o adelantado Miguel Lopez de Legazpi, tendo participado na conquista do território e na sua defesa. Participou igualmente da campanha militar do Maluco liderada pelo governador de Manila Gomes Perez. Ocupou cargos de importância como o de embaixador, nomeadamente, nos contactos entre Manila e a China. 
Sarmiento tinha "cabedal" para o fazer, pois conforme ficou declarado mantinha soldados a soldo e vários navios equipados por si.

A 5 de Julho, Sebastião Rodrigues Soromenho parte do porto de Cavite para iniciar a sua missão. A expedição vai decorrendo, com o piloto-maior ocupado a registar de forma detalhada a costa da Califórnia, e de tal forma o faz que Jaime Cortesão num rasgado elogio considera esse texto "o primeiro roteiro objectivo das costas ocidentais dos EUA"

\section{O cabo Mendocino}

A 4 de Novembro de 1595, avistam a costa da Nova Espanha, estando situados a $42^{\circ}$. Soromenho preparou-se para o descobrimento acercando-se o mais que pode da costa, ficando a duas léguas de terra. Na manhã do dia seguinte, abriu as velas e continuou rumando ao longo da costa. Esta hera muy braua y peligrosa por auer mucha rebentason de mar en tierra acaussa de muchos yslotes y arresifes que auia çerca de la tierra ${ }^{45}$ e por isso não pode aproximar-se mais, até para averiguar que fumo era aquele que via do navio. Neste dia descobriu um "bajo" que não distava mais de uma légua do mar que o obrigou a afastar-se de terra. A letra miudinha para caber no espaço das entrelinhas, o escrivão escreveu: hera el cauo mendosino. Este apontamento feito de forma tão discreta e modesta não está vazio de significado. Bem pelo contrário, já que em pelo menos duas obras historiográficas portuguesas Soromenho é tido como o responsável pelo descobrimento do Cabo Mendocino, conclusão com que não podemos deixar de discordar após longa ponderação.

Um dos primeiros textos que lemos sobre Sebastião Rodrigues Soromenho foi a entrada na Enciclopédia Luso-Brasileira de Cultura ${ }^{46}$, onde Jorge Preto Guerra, ao traçar a biografia do piloto, afirma sem evidenciar qualquer dúvida que este foi o descobridor do Cabo Mendocino, nome que teria sido escolhido para honrar o vice-rei António de Mendoza. Esta entrada foi com certeza retirada de um trabalho seu de 1951, cujo título não podia ser mais explícito: Sebastião Rodrigues Sermenho, Descobridor do

44 Jaime Cortesão, citado no texto de Jorge Preto Guerra incluído na Enciclopédia LusoBrasileira de Cultura.

45 AGI, Mexico, 23, N.5013, f. 3.

46 Guerra, Jorge Preto: "Soromenho, Sebastião Rodrigues", Enciclopédia Luso Brasileira de Cultura, Lisboa, Editorial Verbo, 1975,vol.17, págs. 562-3. 
Cabo Mendocino ${ }^{47}$. Na bibliografia, o autor cita Celestino Soares e o seu artigo California and the Portuguese, de 1939, que defende a mesma ideia. Jaime Cortesão elogia a novidade que consistiu o roteiro de Soromenho sem, no entanto, lhe atribuir a prioridade no descobrimento. Rafael Monteiro, dedicado investigador da história da sua terra e da sua gente, também não faz tal referência. Assim como o fizeram os historiadores norteamericanos que escreveram em datas próximas às dos artigos mencionados, como é o caso de Henry Wagner e Chapman, ou investigadores que publicam em Espanha como Juan Gil e Sylvia Hilton, e numa data mais recuada Francisco Morales Padron (este historiador vai mais longe, atribuindo o feito a Bartolomé Ferrelo, piloto a quem coube liderar a expedição após a morte de Cabrilho). ${ }^{48}$ Se consultarmos o volume VII da obra de referência geral Historia General de España y América, obtemos a mesma informação ${ }^{49}$. Esta noção coloca os dois autores em dissonância com os restantes estudos biográficos sobre Soromenho e sobre João Rodrigues Cabrilho, este sim tido como o responsável pelo descobrimento do disputado cabo.

Em que se fundamentam então Jorge Guerra e Celestino Soares para atribuírem tal título a Soromenho é a pergunta que se impõe. Quanto a Jorge Guerra, o seu texto na Enciclopédia Luso-Brasileira de Cultura não adianta qualquer informação, o que se pode explicar por tratar-se de um texto breve cuja bibliografia remete para o artigo. Traçando o caminho até Celestino Soares, constatamos qual a base em que assenta o seu raciocínio: por um lado as fontes de 1596, e por outro, o facto de o cabo descoberto por Cabrilho, ou mais precisamente por Barlomé Ferrelo, ter sido o cabo das Fortunas $\left(\mathrm{a} 41^{\circ}\right.$ ) hoje conhecido como Falso Cabo ou Falso Mendocino ${ }^{50}$.

A resposta está pois na frase repetida nas fontes documentais específicas sobre a viagem e produzidas por aqueles que nela participaram que servem de base à presente investigação: "En el nauio Sant Agustin que uino al nиеио descubrimiento al cabo Mendocino" pode-se ler entre as primei-

47 Guerra, Jorge Preto: "Sebastião Rodrigues Sermenho, Descobridor do Cabo Mendocino" Bazar das Letras das Ciências e das Artes (suplemento de A Voz de 29.9.1951).

48 “... Bartolomé Ferrelo, sustituto de Cabrillo, asume el mando y ordena continuar la ruta al Norte, singlando hacia los $40^{\circ}$, frente a un cabo que llama Mendocino." Morales Padron, Francisco: História del Descubrimiento y Conquista de America, Madrid, Editora Nacional, 1973, 3. a edição, pág. 343.

49 Historia General de España y América, Madrid, Ediciones Rialp, 1982, Tomo VII, pág. 484.

50 Leia-se respectivamente as páginas 40 e 44-45 de Celestino Soares: California and the Portuguese, Lisbon, SPN Books, 1939: "There are various documents referring to this voyage, which was always known as "the discovery of Cape Mendocino"; and among these documents is the report of Sermenho himself" e "The present name of this cape is False Cape, or False Mendocino; it lies five miles to the North of Cape Mendocino." 
ras frases do derrotero de Pedro de Lugo. O roteiro de Soromenho não discorda: "Relacion de lo sucidido en el uiaje que yo el capitan Sebastian Rodriguez cermeño boy a hazer en lo tocante al descubrimiento del cabo mendozino es lo seguinte" é a frase de abertura. E não esqueçamos o texto com os testemunhos de Soromenho e alguns membros da tripulação informando sobre a qualidade da terra feito no decurso da viagem: "En el puerto e baya del nueuo descubrimiento del cabo mendosino"51. Só estes exemplos nos diriam que as nossas dúvidas não tinham cabimento.

A nossa pergunta prende-se em primeiro lugar com o silêncio ostensivo a que estes mesmos documentos remetem o dito descobrimento, quando não fazem para a descoberta da baía de S. Francisco. Se excluirmos as frases iniciais, não encontramos menção a esse descobrimento e isso não faz sentido. Para quê destacar um acontecimento para depois não lhe dar a ênfase correspondente? Pedro de Lugo "espreme" o cabo no espaço das entrelinhas. No relato de Soromenho, o facto é descrito não como uma novidade, mas como o reconhecimento da linha da costa:

Y uiniemos costeando como media legua de tierra se descubrio y uio un bajo que podia tener como una legua de la mar el qual era el cabo Mendozino por que desde alli corrio la costa al sueste y costa de poniente al norte quarta al nordeste. ${ }^{52}$

É verdade que quem ler apenas o seu roteiro, fica sem saber que houve uma cerimónia de posse solene da baía de S. Francisco. Mas é igualmente verdade que a descoberta da baía de $\mathrm{S}$. Francisco não ocupa as primeiras linhas das descrições.

Em segundo lugar está a escolha do nome para o cabo. Era comum dedicar o novo local à honra dos monarcas, rei ou rainha, ou de uma figura grada como o vice-rei. António de Mendoza foi o primeiro vice-rei do México, tendo ocupado o cargo entre 1535 e 1550. Ora a data mais recuada que dispomos coloca Soromenho na carreira das Filipinas no início da década de ' 80 do século XVI. Acrescente-se que a querer honrar alguém, e com mais do que justificadas razões para o fazer, Soromenho devia esse tributo a Velasco, o homem que o escolheu e apresentou a Filipe II como capaz de cumprir a missão. O cabo seria assim Velasquino e não Mendocino. Se cabe a alguém fazer essa homenagem será a João Rodrigues Cabrilho que entre 1542 e 1543 percorreu esta mesma costa a mando de António de Mendoza. Partindo da análise dos documentos, afirmamos que não se trata de um des-

51 AGI, Mexico, 23, N. 50\4, f.1.

52 AGI, Mexico, 23, N 50, f. 7. 
cobrimento no seu sentido absoluto, antes um novo descobrimento como as próprias fontes afirmam, um redescobrir e mapear com clareza desta vez um acidente geográfico identificado cinquenta anos antes.

Retomemos a viagem. A 6 de Novembro ancorou na baía a que deu o nome de S. Francisco e da qual tomou posse solene a 7 de Novembro, conforme descrito no roteiro:

Y el dicho dia que salto el dicho capitan con la dicha jente en tierra pidio a todos le fuesen testigos como en nombre del Rey nuestro señor tomaua posesion de la tierra e puerto, al qual le pusso por nombre la baya de San Francisco que la bautizo el Reverendo [6] Padre fray Francisco de la Conçepçion de la horden de Sant Francisco de los Descalços que uiene en la dicha nao. ${ }^{53}$

Não era a primeira vez que esta baía era reclamada como parte de um império europeu. Francis Drake na sua viagem inaugural nos domínios marítimos espanhóis tomara posse em nome da rainha Isabel de Inglaterra a 7 de Junho de 1579, baptizando-a de Nova Albion numa escolha que remete de forma evidente para a memória do seu país natal. ${ }^{54}$

Foi também nestes dias que teve lugar o primeiro encontro entre a tripulação e a população índia local. Pela descrição do escrivão ${ }^{55}$, o encontro foi amistoso, reportando-nos imagens de outros encontros ao longo da costa americana, nomeadamente entre os portugueses e os índios do Brasil ${ }^{56}$. (Sabemos que nem sempre foi assim, basta recordar as viagens de Magalhães e de Cabrilho.) Embora incapazes de compreender o que lhes fora dito, o comportamento do índio não suscitou receio e Soromenho repete os gestos de amizade de outros europeus em terras americanas: oferece-lhe

53 AGI, Mexico, 23, N.5013, ff. 6 e 7.

54 "The voyage and course which sir Francis Drake held from the haven of Gualtulco, on the backside of Nueva Espanna, to the Northwest of California, as far as 43 degrees, \& from thence backe againe to 38 degrees, where in a very good harbour he graved his shippe, entrenched himself on land, called the countrey by the name of Nova Albion, and tooke possession thereof on the behalf of her Majestie" in Richard Hakluyt: The Principal Navigations, Voyages, Traffiques \& Discoveries of the English Nation, Glasgow, James MacLehose and Sons, 1904, vol. IX, pág. 319-326.

55 AGI, Mexico, 23, N.50\3, ff. 5 e 6.

56 Referimo-nos às descrições de Pêro Vaz de Caminha na carta ao rei D. Manuel sobre a descoberta do Brasil.

Os roteiros foram alvo de estudo por parte de antropólogos e arqueólogos. Veja-se Araceli González Vasquez "Aprovechamiento de recursos vegetales en Califórnia: los cazadores-recolectores en las fuentes escritas del siglo XVI", Nível Cero, 1999. É uma publicação do Grupo Arquelógico Attica sediado em Satander (Cantabria); Robert Fleming Heizer: "Archeological Evidence of Sebastian Rodriguez Cermeño's California Visit in 1595", California Historical Society Quarterly, São Francisco, v. 20, n. ${ }^{\circ}$, Dec. 1941.

AGI, Mexico, 23, N.50\3, ff. 9 e 10. 
mantas, seda e um barrete colorido. Note-se que Soromenho levava o navio carregado com produtos para comerciar com os povos que viesse a encontrar. Uma avaliação superficial demonstrou cabalmente não serem os Miwok detentores de capital atractivo para qualquer transacção, que como sabemos nunca virá a ocorrer. O naufrágio tornou estes índios nos herdeiros casuais de tamanha riqueza que receberam com descaso. ${ }^{57}$

Quinze dias mais tarde, a 30 de Novembro, dá-se o naufrágio do San Agustin enquanto permanecia ancorado na baía. Marcado por anteriores tempestades e carregado com os produtos com os quais Soromenho e Sarmiento tinham planeado obter lucros através de eventuais trocas com as populações que viessem a contactar, foi empurrado para terra onde se despedaçou, provocando a perda dos mantimentos e da carga. A referência ao naufrágio é feita de maneira sucinta pelo escrivão do navio, não expressando o impacto que teve no presente imediato de todos e as repercussões que soubemos veio a ter futuro:

En treinta de nobienbre auiendose perdido $\left[9^{\circ}\right]$ el dicho nauio Sant Agustin con los bastimentos que auia. $O$ roteiro de Soromenho rege-se pela mesma austeridade, não indicando sequer a data: Por auer como ay tres leguas la tierra adentro que yo bide y los demas espanoles que lleue en mi conpanía a buscar bastimentos por tener necesidad dellos abiendo se perdido el nauio.

A descrição mais elucidativa é-nos dada pelos testemunhos recolhidos por Pedro de Lugo no dia e local do naufrágio:

En el puerto e baya del nueuo descubrimiento del cabo Mendosino en el Real de Santa Fee treinta dias del mes de nobienbre de mill y quinhentos y nouenta e çinco por ante mi Pedro de Lugo escriuano del rey nostro señor el capitam Sebastiam Rodriguez Sermeño piloto mayor del dicho descubrimiento dixo que por quanto a causa de auerse perdido el nauio Sant Agustin que traxo que ofresçio a el rey en la cuidad de Manila el capitan Pedro Sarmento estando surto en este dicho puerto sin poder sacar cosa ninguna de los bastimentos y las demas hazienda que traya como consta de la aueriguaçion en esta fecha e porque ay çerca de ochenta personas que sustentar y no ay bastimentos que dalles ni que poder lleuar en la lancha que se esta acabando en que a de yr e tiene notiçia que çerca deste Real ay bastimiento con que poder remediarlo e para ello a acordado auiendo tomado pareçer con las personas deste real de quien se deuia tomar que conuenia al bien de todos y seruiço del Rey yr a buscar los bastimentos dexando en este Real por su lugar theniente para que acuda a dar horden y mandar que se acabe la obra que falta de la dicha lancha ya lo demas que se ofresçiere en lo tiempo de su ausencia al capitam Francisco de Chaues ques persona de toda confiança $[\ldots . .]^{58}$.

57 AGI, Mexico, 23, N.50, f. 10.

58 AGI, Mexico, 23, N. 50\4, ff. 1 e 2. 
O naufrágio ocorreu com o navio ancorado na baía, facto que justifica a avaliação posterior pelas autoridades que a responsabilidade cabia a Soromenho, cuja apregoada perícia náutica foi insuficiente para evitar o desastre. Perdidos todos os mantimentos e fazendas, urgia construir a lancha trazida para o descobrimento, e que agora assumia uma função vital para os sobreviventes. Quaisquer planos de realizar negócios lucrativos com portos ao longo da costa com que Soromenho se tenha ocupado durante os cinco meses de viagem desde que largara de Cavite, conforme previsto no contrato, tinham sido engolidos pelo mar. Assim como o hábito da ordem de Cristo, mercê com que Filipe II se preparava para lhe atribuir em recompensa pelos seus serviços.

Perante a adversidade, Soromenho assume uma outra missão, a sobrevivência da sua tripulação. A partir daqui, a viagem prossegue na lancha a que é dado o nome de Sant Buenaventura e iniciado o penoso caminho de regresso $^{59}$. Navegando para Sul, chegaram à baía de San Luis Obispo, à ilha hoje conhecida por San Martin. A 7 de Janeiro de 1596 chegou à costa, já colonizada por europeus, no porto de Chacala, a norte de Cabo Corrientes. Daqui seguiu para o México, onde redigiu o relatório e roteiro da viagem, o qual terminou a 24 de Abril de 1596. Note-se o extraordinário sentido de dever de Soromenho, que mantém o registo dos acidentes da costa após o naufrágio, quando a sua sobrevivência e a da sua tripulação, mais que justificaria, e perdoaria, que o deixasse de fazer. No derrotero de Pedro de Lugo, escrivão real que seguia a bordo, é realçado o desespero dos passageiros e tripulação que repetidas vezes pedem ao navegador que não demore a viagem. A perda de todos os mantimentos confrontava-os com uma morte trágica.

Na documentação relativa a esta viagem, consta uma carta dos funcionários régios de Acapulco dirigida ao Vice-rei de Nova Espanha, de 1 de Fevereiro de 1596, em que se dá conta do naufrágio da nau San Agustin:

El miercoles 31 de henero de este año entró en este puerto un barco que llaman en Philipinas Viroco y en él Juan de Morgana piloto, quatro españoles marineros, cinco yndios y un negro, que diron nueva de que el navio San Agustin del descubrimiento se perdio en una costa donde dió y se hizo pedazos,y que se haogo un fraile descalzo y otra persona de las que en el venian y de setenta hombres ó mas que se metieron en este barco solo vinieron estos porque el capitan y piloto del dicho navio Sebastian Rodriguez Cermeño con los demas desembarcaron en el puerto de Navidad y entien-

59 Sobre esta embarcação, já encontramos outras versões: que feita a partir dos destroços do San Agustin ou do tronco de uma árvore cortada nas imediações. 
den estarán ya en esa cuidad el subceso y discurso de su viaje y perdida del navio y en la parte que consta por declaracion que con juramento hizo el dicho piloto Joan de Morgana que es con esta y el varco visitamos y en el no venian ningun genero de mercadorias, los hombres casi desnudos a causa de ser tan chico que por milagro parece haver llegado a esta tierra con tanta gente. ${ }^{60}$

Como lhe competia, o vice-rei de Nova Espanha transmitiu a Madrid o desfecho da empresa de Soromenho, em carta datada de 19 de Abril de 1596, dois meses e meio após a chegada a Acapulco da embarcação feita com os destroços da nau San Agustin. Já não é Luis de Velasco quem assina a carta, e que, recorde-se, sugerira o nome do piloto português, mas Gaspár de Zúñiga y Acevedo, Conde de Monterrey, que ocupou o cargo de vice-rei entre 1595 e 1603. Nela dá conta do estado em que chegou a tripulação e do clima de acusações mútuas sobre a quem caberia a responsabilidade pelo naufrágio, conforme consta da documentação que lhe enviara a audiencia em Guadalajara. É o momento em que tem de decidir se há alguma pena a cumprir. E se for caso disso, deve-se, no seu entender, demonstrar alguma compaixão por tudo o que sofreram. Transcrevemos a carta do vice-rei Conde de Monterrey na íntegra por ser o único documentos oficial a fazer um balanço da expedição de Soromenho:

Sobre la perdida del navio S. Agustin que venia de las yslas de poniente hacer el descubrimiento de las costas de la mar del sur, como vuestra magestad fué servido de mandar al Virrey Don Luis de Velasco escribí a vuestra magestad en el segundo de aviso lo que acaba duplicado, despues de llegado, alguna gente que se salvó de la que venia en el navio y entre ellos los oficiales del que se pretendem culpar unos a otros como siempre acontece en semejantes subcesos, enviome y remitiome la audiencia de Guadalajara ciertos auctos que por su horden se hicieron entre ellos, habiendo tomado tierra en aquel distrito, quedandose mirando y que en caso que resulte culpado alguno y parece conviniente castigarle, se hará. Aunque es arta compasion de lo que an padecido despues que dió al traves el navio, de la mucha perdida de hacienda que hicierón en él; de lo que fuere necesario avisar a vuestra magestad se dará quenta y por ahora solo se me ofrece decir que en descubrimiento de los puertos dice el piloto que procuró cumplir con su obrigacion en la lancha con que vinieron despues de la perdida del navio y trae escripta una relacion cuya copia será con esta. Pero yo lo é examinado en presencia del cómitre y contramaestre que son ambos platicos y aunque conforman en algunas cosas diferen en otras y me parece que se convence y colige claro que algunas bayas de las principales y donde mas se podia esperar de hallar puerto las atravesaran de punta a punta y de noche y otras entraron poco, a todo debió

60 "Capitulo de carta de los oficiales reales de Acapulco, al Virey de Nueva España, fecha en Acapulco á 1. ${ }^{\circ}$ de Febrero de 1596 dando noticia de la perdida de la nao San Agustin", Documents from de Sutro Collection, pág. 31-33. 
dar ocasion forzosa la hambre y enfermedad con que dicen que venian que los haria apresurar el viaje. Y asi entiendo que no está en cuanto á este descubrimiento cumplido el intento de vuestra magestad y todos convienen en que esta diligencia no se debia de intentar de tornaviaje de las yslas y con navio cargado sino de esta costa yendo siempre por ella adelante. ${ }^{61}$

Na carta do Conde de Monterrey, sublinhámos a passagem que merece particular destaque, por nela fazer o balanço da viagem de Soromenho, baseado no roteiro escrito pelo navegador e na consulta que fez ao contramestre e comitre da embarcação. O conde é claro na sua avaliação. A procura de um porto capaz de servir de apoio às naus da rota de Manila não foi bem sucedida. Os perigos a enfrentar por navios carregados na tornaviagem aconselham que se mantenha a navegação ao longo da costa, para evitar o perigo de naufrágio e a perda de tão precioso carrego. É à luz desta recomendação que a viagem de Viscainho em 1602 é organizada. Este parte de Acapulco e não das Filipinas, poupando o desgaste de quatro meses no mar e não transportando mercadorias para comerciar.

Nos anos imediatos à viagem, as referências ao naufrágio eram claras em apontar um culpado. Em 1602, Francisco Bolaños, o piloto de Soromenho, é citado no roteiro de Viscainho. Em 1609, D. Elvira, a viúva de Pedro Sarmiento reforça a ideia. Esta acusação, que partilhava com as autoridades da época, deixou a sua marca, justificando para autores como Jaime Cortesão ${ }^{62}$ o desconhecimento generalizado do nome de Soromenho

61 "Capitulo de una carta a Su Magestad del Virey de la Nueva España Conde de Monterrey fechada en Mexico a 19 de Abril de 1596 con noticias de la perdida de la nao San Agustin y lo que se consiguió descubrir con ella", Documents from de Sutro Collection, pág. 35-39.

62 "Infelizmente a perda do galeão San Agustin e, com ele, a das mercadorias que trazia do Oriente, fizeram empalidecer aos olhos dos mercadores e do próprio governador da Nova Espanha, as notáveis façanhas de marinheiro e explorador, realizadas por Sermenho.” Jaime Cortesão, Os portugueses no descobrimento dos Estados Unidos, Lisboa, Seara Nova, 1949, pág. 80. A avaliação de Corteseão faz eco da de Henry Wagner: "The most cruel thing that happened to Cabrillo, however, was that he was deprived of all evidence on the maps of California of his visit to this coast. This was due to Sebastián Vizcaino, who, in 1602 and 1603, covered much the same ground as did Cabrillo. Although he had strict instructions from the viceroy not to change any of the names then in use on this coast, he took advantage of the more nearly accurate observations of his pilots to pretend that he could not locate Cabrillo's places and so endowed the coast with an entirely new set of names, which in the main persist to the present day." In Henry R Wagner, Juan Rodríguez Cabrillo - Discoverer of the coast of California, California Historical Society, San Francisco, 1941, pág. 30-31. W. Michael Mathes refuta firmemente que Vizcaíno tivesse tido a intenção de apagar o mérito das descobertas de Cabrilho e Soromenho, usando como prova os roteiros de Gerónimo Palácios e do frade António de la Ascención. W. Michael Mathes: "The Puerto De Don Gaspar. A Note On An Erroneous California Place Name", The Journal of San Diego History, Fall 1974, Volume 20, Número $4<$ http://sandiegohistory.org/journal/74fall/puerto.htm> [26/08/2003]. 
nos nossos dias. $\mathrm{O}$ naufrágio atribuído à incúria do navegador enublou a importância do seu feito aos olhos dos seus contemporâneos, e só recentemente estudos históricos têm recuperado e realçado o alcance da viagem de exploração por ele empreendida ao longo da costa da Califórnia. A esta interpretação acrescentamos a viagem de Viscainho de 1602, que resultou na redacção de roteiros detalhados, com desenhos da linha de costa com marcações precisas dos diferentes tipos de acidentes geográficos e surgidouros, que foram amplamente utilizados até ao século XVIII.

\section{O contributo da viagem de Soromenho}

A análise da viagem de Sebastião Rodrigues Soromenho adquire maior relevância se enquadrada no contexto do processo de descoberta, exploração e registo da América Hispânica, mais precisamente da costa da Califórnia. A procura de pontos de apoio ao A rota do galeão de Manila tinha uma significativa importância para o Império espanhol, além de ter um peso considerável de interesses relacionados ao vice-reino da Nova Espanha. As dificuldades naturais da viagem e a adicional ameaça inglesa nos finais do século XVI promoveram acções dos vice-reis com o objectivo de assegurar os lucros desse empreendimento e por isso tornou-se fundamental um melhor conhecimento da costa da Califórnia. A viagem de Soromenho é um capítulo essencial nessa política de afirmação da presença espanhola na região.

A base sobre a qual assenta esta premissa decorre da evidência que a expedição de 1595 não se tratou de um acto isolado, nascido de circunstâncias efêmeras, mas pelo contrário, deve ser encarado como o retomar de esforço de descoberta que tem as suas raízes na empresa de João Rodrigues Cabrilho, em 1542, e que viu a sua conclusão com Sebastião Viscaiño, em 1602. A primeira decorreu cerca de cinquenta anos antes da expedição de Soromenho e tem um duplo significado. Por um lado, abriu a rota sul-norte até às proximidades do cabo Mendocino, ponto na costa que como constatámos está directamente implicado com a rota percorrida posteriormente pelo piloto sesimbrense. Por outro, João Rodrigues Cabrilho representa mais um caso documentado da presença e contribuição dos portugueses na descoberta e exploração da América Hispânica, no seu caso, primeiro como soldado e depois como capitão de um navio. Estamos cientes que a lista de descobridores portugueses que cruzaram o imenso território ultramarino 
espanhol, quer por terra ou por mar, é extensa. Alguns já referenciados como os de Estêvão Gomes e Pedro Queirós.

A viagem de Sebastian Viscaiño foi a resposta imediata das autoridades régias locais ao desfecho da de Soromenho, entendida na altura como um fracasso devido ao naufrágio na baía de São Francisco. A análise dos acontecimentos leva-nos a ter outra leitura deste trágico acontecimento, à luz do que hoje se sabe sobre as duras condições em que se realizava o percurso entre as Filipinas e a Nova Espanha. As autoridades da Nova Espanha não foram cegas a estes factores de risco, e quando, em 1602, enviam Sebastian Viscaiño numa nova tentativa, denota-se um maior rigor na preparação da expedição. Esta já não parte de Manila, mas de Acapulco e a bordo segue uma junta de cosmógrafos, que presta conselho e regista com detalhe todas as informações relativas a pontos para aguada, recifes e recursos naturais. A partir desta recolha foram feitos vários roteiros desta viagem, entre os quais o de Geronimo Martin Palacios que contem um rol extenso de informações acompanhado por ilustrações do recorte da linha de costa e portos feitos por Enrico Martinez.

Sebastião Rodrigues Soromenho surge diante de nós como uma personagem típica da expansão e descobrimentos ibéricos: um homem em quem o espírito de aventura e desejo de ter "cabedal" estão aliados a um sentido de dever para com o rei, temor a Deus e lealdade para com a tripulação do seu navio. Um piloto de reconhecida capacidade, experiente, zeloso, que aceita o risco e vê nesta proposta a oportunidade de ter o seu quinhão. O ter nascido numa localidade costeira familiarizou-o desde cedo com o mar e a vida no mar tornou-se o destino mais natural. Deixou a família em Portugal, fazendo de Beatriz Afonso mais uma de muitas viúvas de marido vivo. E ainda como um homem da sua época tem como valores ser honrado, temente a Deus e previdente, particularmente no que dizia respeito à salvação da alma e à obtenção de um lugar entre os justos, cuidou de incluir a sua mulher no testamento bem como às obras piadosas da Santa Casa da Misericórdia. Nisto Sebastião Rodrigues Soromenho não se distingue de centenas de outros portugueses para quem as rotas da Índia, Extremo-Oriente ou do novo Mundo eram os degraus necessários para a ascensão social e fortuna. O seu feito, porém, inscreve-o entre os maiores navegadores do Pacífico.

Recibido el 14 de diciembre de 2005 Aceptado el 10 de marzo de 2006 